\title{
Soft Tissue Sarcoma of the Retroperitoneum TNM Finding v8
}

National Cancer Institute

\section{Source}

National Cancer Institute. Soft Tissue Sarcoma of the Retroperitoneum TNM Finding v8. NCI Thesaurus. Code C136792.

A finding about one or more characteristics of soft tissue sarcoma of the retroperitoneum, following the rules of the TNM AJCC V8 classification system. This classification system applies to common sarcomas in the retroperitoneum. (from AJCC 8th Ed.) 